\title{
COLLABORATION FOR INNOVATION IN SMALL CEE COUNTRIES
}

\author{
Viktor Prokop, Jan Stejskal, Oto Hudec
}

\section{Introduction}

Firms are struggling to gain competitive advantage to resist the ever-increasing global market pressures. Many strategic management studies have identified several essential pillars of building firm's strategy, often highlighting positive relationships between the use of human resources and the firm performance (Collins \& Clark, 2003; Wright et al., 2005). Thus, human capital as the stock of productive knowledge and skills embodied in individuals is a crucial strategic production factor. Knowledge and human resource are intrinsically related concepts since it is people who can learn, generate, utilise and disseminate knowledge in collaborative networks. Knowledge is a primary input in the innovation process, and the ability to use knowledge is crucial in achieving high innovation performance and the strategic competitive advantage (Bock, Opsahl et al., 2012). Innovation in firms is embedded in social and knowledge networks of collaborators and knowledge elements linkages (Wang, Rodan et al., 2014; Nieves, Quintana, \& Osorio, 2016). This obviously points to the importance of a high-quality internal environment that enables firms to come up with new ideas to be transformed into future innovations.

From a microeconomic point of view, firmperformance is rather a multidimensional problem. It includes both the ability to produce quickly and inexpensively, which is conditioned in particular by transfer of knowledge (Ritala, Olander et al., 2015) and the ability to work with new technologies (Ramadani, AbaziAlili et al., 2017). Another set of determinants is denoted as the innovation environment or ecosystem (Trippl \& Bergman, 2014). Numerous knowledge-based or cooperationbased relationships, entrepreneurial networks exist among entrepreneurs and other economic entities such as R\&D organizations, universities, but also various government agencies, NGOs, and regional governments. Cooke (2016) highlights the collectiveness of innovation and importance of relationships among "strange attractors" capable of interacting across borders of firms and industries and interconnecting different kinds of creative actors. Although the actors may be in a competitive position, a collaborative capacity creates higher innovation ability eventually in an open innovation environment. The ability to cooperate in the innovation environment creates a synergistic model bringing significant positive effects on the basis of knowledge spillovers to participating collaborating partners.

Therefore, competitive advantage is driven by cooperation in local or regional value chains (local, regional) which are integrated into the global value chains managed by multinational enterprises. It is clear that the innovation environment varies between regions and countries and that distinct determinants act differently. The differences in nature of the innovation environment, cooperation and performance depend on many factors and significant differences between Western European countries and the group of Central and Eastern European (CEE) countries can be expected. After the hard transition period to a market economy, CEE countries have experienced considerable economic growth in the first two decades of the 21 centuries, however was not driven by innovation (Varblane et al., 2007). This is particularly evident in smaller CEE countries, which are more dominated by the multinational enterprises. Eastern European innovation policy models have still been implemented within the centralized and prevailing sectoral policies of science and technology, resulting in weak innovation performance and undeveloped local and regional innovation networks. Thirty years 
after integration into the European economy, CEE countries still exhibit low trust and limited cooperation between the triple helix entities (industry, public institutions, and knowledge institutions) and a lack of brokers and attractors enabling effective knowledge transfer and exploitation (Hudec, 2015). Following the previous arguments, the main focus of the paper is to provide an examination of the impact of the cooperation with different kinds of innovation partners on the product innovation performance of the manufacturing companies in small CEE countries (Czech Republic, Slovakia, Hungary, Slovenia and Estonia).

The rest of the paper is structured as follows. The next section covers the theoretical background for understanding the determinants of innovation activities leading to the formulation of the key research questions and development of the model framework. Section 3 provides the research methodology and the characteristics of the dataset, and Section 4 lists the research results. In the last Section 5, the results obtained are interpreted and discussed, to conclude and formulate recommendations for future research.

\section{Theoretical Background}

The traditional model of business behavior supposed only short-term effects of innovation due to rapid imitation and absorption of innovation by competitors. Over time, many studies have shown a limited validity of understanding innovation in a globalized and interconnected economy showing the remaining superiority of innovative firms to their rivals for a considerably longer period in different institutional settings (Lööf et al., 2001). Innovation is considered a constitutive element of entrepreneurship in order to persist and prosper in hypercompetitive markets. The relationship between the implementation of innovation activities, and company performance is realized nowadays through long-term strategic planning and building up stronger innovation-based strategic capacities (Beers \& Zand, 2014). Innovations help to maintain company market position, increase the rate of performance and update routines by which firms achieve higher performance (Lööf \& Heshmati, 2006; Chen et al., 2015). Romer (1990) also considers innovation as one of the inputs in the production process, highlighting the institutional environment as a key determinant significantly influencing the efficiency of the whole innovation process.

Earlier empirical results focused on the effect of innovation on firm performance stereotypically testified a positive relationship. Also, as a measure of innovation, mostly R\&D expenditures were used as a proxy variable of innovation. It turned out, however, that such an approach is too simplified and suffering from many shortcomings (Tavassoli \& Karlsson, 2016). Innovation considered only as an input does not take into account several crucial systemic and institutional factors such as sequentiality, learning-by-doing, mutual learning or investments in physical and human capital. Also, R\&D is not a necessary prerequisite for the introduction of new products, as existing knowledge can be acquired from elsewhere. However, product innovations are more dependent on R\&D in high-tech manufacturing industries in comparison to lowtech manufacturing.

Due to high complexity and versatility of the innovation processes, a strong focus of research has been devoted recently to better examine the mechanisms and channels through which new ideas are converted into improved performance. Consequently, there can be several determinants that form or influence the innovation environment and, in turn, influence the ability of firms to generate innovative outputs (Lööf et al., 2001). Diverse effects can occur across sectors as well as individual countries on the basis of the substantial differences in the degree of economic development, cooperation rates, internationalization, openness, type of public policy or the incentive system. Moreover, determinants can influence different stages of the innovation process (from the decision to innovate and investment spending to the relationships between innovation expenditure/ innovation output and innovation output/ performance). Considering this (Lööf \& Heshmati, 2006; Friedman \& Carmeli, 2018), there are several other determinants to be examined related to the factors influencing firms decision to innovate: firm size, export orientation, quality of human capital, chosen innovation strategy, the degree of cooperation with other entities in the market environment, co-operation with the R\&D sector, public support system exploitation, in-house research activities, availability of R\&D public funding, etc. The degree of influence of individual 
determinants is somewhat ambiguous (Hashi \& Stojčić, 2013). Klomp and Van Leeuwen (2001) analyzed the relationships between the different stages of the innovation process and overall economic performance using CIS data, demonstrating a positive impact of sustained involvement in R\&D on innovation outputs. However, other works (Lööf et al., 2001; Caloghiro, Ketata, Sofka, \& Grimpe, 2015; Xiang et al., 2018) do not validate such relationship.

Under different conditions, firm size could be positively or negatively related to innovation due to the different effects of conditions in the institutional environment of the country or region, or a different field of firm specialization. Firm size could be related to performance, as larger firms have higher assets to manage up-to-date fitting innovation, but also more inclining to benefit from the economies of scale and relying on market power strategies. In comparison, small firms are more expected to build on their innovative dynamics (Figueiredo \& Piana, 2018), less participating in R\&D but at a higher intensity and productivity. Often, young and small firms are perceived as the primary drivers of innovation. Performance of firms may be expected to be different across industries as it was shown in the study of the product innovation determinants (Tavassoli, 2018). Higher technological potential usually brings also higher inclination to innovate. Similarly, it is possible to justify the importance of other factors. Human capital, educated and qualified workforce is another key prerequisite for successful innovation, especially on the technological frontier.

Firms, however, exist and operate in different environments, having unequal access to the acquisition of resources and knowledge. An innovation environment (or more narrowly the innovation ecosystem) may have essential attributes significantly influencing firm innovation capabilities and performance. The quality of the institutional settings, cultural values in society, willingness to cooperate with other entities and trust belong to primary environmental attributes. Also, a critical element of the innovation process is the access to financial resources and the accessibility to public subsidies for innovation activities (Mateut, 2018). Consequently, national and regional governments endeavor to play a role of facilitator or enabler of appropriate conditions for co-operation between the economic agents, encouraging firms to engage in co-operative structures such as industrial clusters, regional innovation systems or other knowledge-based cooperative chains. This justifies the need to study in more detail determinants of the business and innovation environment and cooperative behavior as one of the explanatory groups of factors of innovation intensity and firm performance.

Exploring the open innovation in the United Kingdom (Bogers et al., 2017 and many others) confirmed the interest of firms for new combinations of existing technologies to make significant improvements to their existing products. However, cooperation does not automatically lead to innovation, in many cases R\&D cooperation fails (Guisado-González et al., 2018), typically in collaboration with competitors and public research organizations. There are also positive learning effects; firms with experience from previous collaborations can significantly reduce the risk of cooperation failure. Thus, factors of environment and cooperation enrich the theory of innovation, considering innovation as the result of an interaction between firms and their environment, or even as an outcome of the collaboration interactions between wide variety of actors within and outside the firm. In that understanding, co-operation is reflected as innovation stimuli bring access to complementary knowledge and new markets (Della Peruta et al., 2018). Apart from formal inter-institutional co-operation, knowledge spillovers between internal and external parties play a critical role in knowledge transfer influencing firm's innovation capacity and performance (Ritala et al., 2018).

A specific group for investigation of the factors of firm innovation performance is the group of five Central and East European EU member countries (Czech Republic, Slovakia, Hungary, Slovenia and Estonia). Countries of interest have similar historical experience with a centrally planned economy and longterm isolation from Western Europe and its innovation environment, performance and culture (except Estonia). The transition process to the market economy, the complex privatization and the entrance of many foreign investors created a different environment and the behavior of companies in innovation chains (Hudec \& Prochádzková, 2018). It could be 
expected that cooperation with other private and public institutions is less developed and creates other patterns of collaboration and with a different impact on firm performance. As above mentioned, these countries face the same institutional and infrastructural problems which are solved by current industrial (or innovation) public policies. Unfortunately, there are various dynamic determinants influencing the innovation performance, that's why the economic subjects cannot fully exploit their innovation potential.

Therefore, the paper contributes to a body of knowledge on differences in the innovation processes and performance in a group of smaller CEE countries. The main research question is how collaborations with different types of private and public partners influence performance in product innovation.

Logistic regression models are developed for each country separately to see the individual character of each country. In the second part, the datasets are merged for generalizations purposes to examine the microdata details of firms, such as market orientation, company's ownership and public financing.

It could be expected that the overall lower innovation activity compared to the European Union average might be manifested in differences in the nature of cooperation with customers and suppliers, but especially with universities mostly oriented to fundamental research. Further strong impacts on an innovative environment can be expected due to the broad representation of multinational enterprises in all countries and high paternalism in the countries under study.

\section{Data and Research Methodology}

Following the research questions, the models dealt with the manufacturing industries (NACE 10-33) in five small CEE countries: the Czech Republic, Slovakia, Hungary, Slovenia, and Estonia. The countries from the "new" EU membership (entry after 2004) were selected. These countries have a similar historical development (except Estonia) and belong to the same groups of innovative followers according to the European Innovation Scoreboard. For each country, similar innovation policies have been identified that are applied. It allows using the results for benchmarking (Estonia is the benchmark). When selecting countries, the availability of data had to be taken into account.
The dataset comes from the Community Innovation Survey 2010-2012 (CIS), developed as the principal instrument of the European Union monitoring advancement in the field of innovation. CIS uses harmonized questionnaire created for all EU Member States by Eurostat and combines stratified random sampling with exhaustive surveys addressing firms directly. Pre-processing of data made it possible to work with a sample of 8,616 manufacturing firms in total (3,110 Czech; 921 Estonian; 2,798 Hungarian; 869 Slovakian; 918 Slovenian). CIS defines innovation as a new or a significantly improved good or service introduced on the market. It must be new to the firm, but not necessarily new to the sector or market. Also, it is not important if the firm or someone else initially developed the innovation.

As the variables are binary, the logistic regression analysis is used to study the relationship between a set of explanatory variables and discrete responses. The discrete - binary response $Y$ of an individual unit can take only two values, denoted by 0 or 1 . Similar to previous related studies (Coad \& Rao, 2008; Schneider \& Spieth, 2013) the empirical analysis was performed by using binary logistic regression models. For binary variables, the ratio of the probability of success over the probability of failure defines so-called odds of success. The monotonic logarithmic transformation from probability to odds results in the range of odds from 0 and positive infinity. In logistic regression, the logit transformation of the outcome variable is assumed to have a linear relationship with the predictor variables. The logistic regression model is specified as follows (Retherford \& Choe, 2011):

$$
\begin{aligned}
& \ln \left[P_{i} /\left(1-P_{i}\right)\right]=\beta_{0}+\beta_{1} \times X_{1 i}+ \\
& +\beta_{2} \times X_{2 i}+\ldots+\beta_{n} \times X_{n i},
\end{aligned}
$$

where subscript $i$ denotes the $i$-th observation in the sample, $P$ is the probability of the outcome, $\beta_{0}$ is the intercept term, and $\beta_{1}, \beta_{2}, \ldots \beta_{n}$ are the coefficients associated with each explanatory variable $X_{1}, X_{2}, \ldots, X_{k}$. A positive value of a coefficient means that the log of odds increases as the corresponding independent variable increases. The coefficients in the logistic regression are estimated by the maximum likelihood estimation method (for further explanation see e.g. Retherford and Choe (2011)). Econometric verification of the 
model was performed by the homoskedasticity test.

First, the explanatory variables extracted from the CIS data are tested for collinearity. Spearman rank correlation coefficient rho measures the strength of the linear relationship between each two variables (Hudec et al., 2007). Correlation between two variables is shown is the value of rho is significantly different from zero (rho ranges between $-1 \leq$ rho $\leq 1$ ).

Subsequently, the collinearity among the independent variables was tested by Variance Inflation Factor (VIF) for each regression model. Multicollinearity was not found in the models (VIF < 5). All calculations were performed with the statistical software IBM SPSS.

The methodological process consists of several steps:

First. To reveal the impact of the cooperation of the manufacturing companies with different kind of partners in the production of product innovations, the process started with all available CIS data. Data of individual countries were processed separately. The idea was to discover types of partners in cooperation (private and public entities, see Fig. 1) that have the most significant impact on product innovation. These predictor variables have also entered into following models. Already at this stage of the research, it is possible to see first results about the kind of partners influencing product innovations in all five countries.

The empirical model aims to investigate the effects of co-operation with different kinds of entities on the dependent variable innovation activities (see Fig. 1). CIS data made it possible to consider following independent variables (inputs) that represent distinct cooperation partners, whose importance is justified below:

Group of private entities:

- COGP: other enterprises within enterprise group; firms from enterprises groups are able to draw on resources from within their wider groups and not needing to seek as many resources externally - it can help them to reduce costs and bring benefits from knowledge spill/overs (Tether, 2002);

- COSUP: suppliers of equipment, materials, components, or software; firms that cooperate with suppliers have a higher propensity to product innovation as well as radical innovations (Minguela-Rata et al., 2014) and influence firms' profitability (Brito et al., 2014);

\section{Fig. 1: General cooperation model}

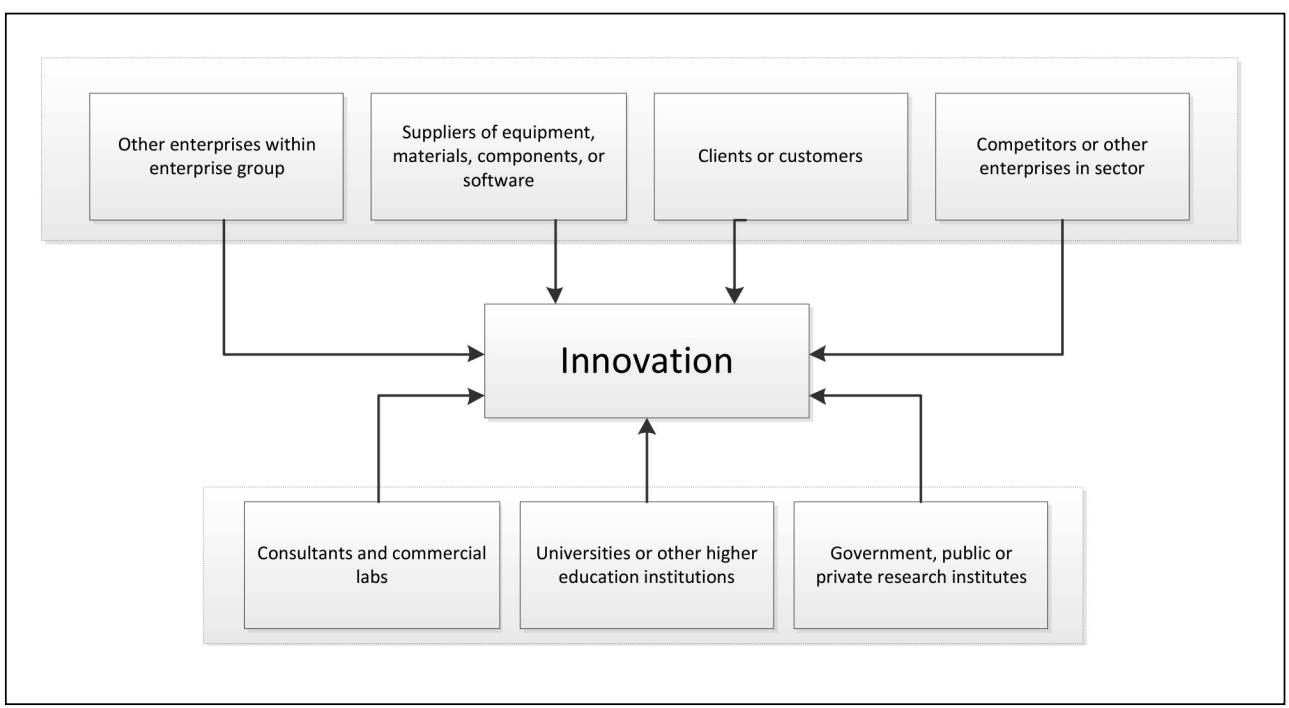


- COCUS: clients or customers; this kind of cooperation plays an important role in dealing with changes in customer preferences, shortening product lifestyles (Fossas-Olalla et al., 2010). Customers or users involved in the innovation process change considerably functions developed in the R\&D and marketing departments, such as new product design and development (Sánchez-González et al., 2009);

- COCOMP: competitors or other enterprises in the sector; cooperation with competitors mitigates the inefficiencies of competition, improves information exchange, helps to gain economies of scale, reduces uncertainty and risks and speeds up new product development (Wu, 2014);

Group of public entities:

- COCONS: consultants and commercial labs; helps firms and their managers to solve problems in research, development, production or a business, they are not fully trained or having sufficient resources, equipment and market experience (Cvijanović et al., 2015);

- COUNI: universities or other higher education institutions; a source and generator of new knowledge and ideas (Prokop \& Stejskal, 2017). University knowledge production is vital for industrial innovation, patent production and creation of knowledge spill-overs (Maietta, 2015);

- COGOV: government, public or private research institutes; institutions that tend to promote research environments, conducive to cooperation between academic researchers and private companies and attempt to push academic researchers towards research and related interactions with industry (Boardman, 2009).

Second. In the second part, the model is constructed so as to identify the predictors, the variables having a significant impact on product innovations across countries. In this case, the analysis is not done for each country separately; the merged dataset of all five countries together is used instead. This makes it possible to obtain and generalize the results on the whole group of CEE countries. Due to the different country sample sizes, it was necessary to equalize sample sizes to be approximately large. Therefore, in the case of two countries, a systematic random selection of the original files was used (Czech Republic and Hungary). The resulting sample sizes entering the econometric analysis were as follows: CZ 1,036, HU 932, ET 921, SK 869 and SL 918 enterprises. This approach ensured the comparability of the countries in the model.

Third. To extend the body of knowledge on innovation and performance of firms, three variables were also added to the model as control variables: the market orientation (MAR), company's ownership (OWN) and public financing (FUND). The merged dataset of five CEE countries was again used to investigate the impact of different kinds of cooperation partners on product innovations by the binary logistic regression model.

\section{Regression Models and Empirical Results}

In the following part, the results of regression models are shown for each of the five countries. Firstly, the effect of cooperation with seven kinds of partners on firm innovation is investigated. In the first model, we examined the dependency between collaboration with different types of entities involved in the innovation processes (private and public) on company performance. Hence the binary dependent variable $Y$ in the logistic regression is the response to the question in the CIS survey: "did your enterprise co-operate on any of your innovation activities with other enterprises or institutions?"

The results of the impact of each type of entity on firm performance are shown in Tab. 1. Product innovations are significantly dependent on cooperation with customers in all countries. This finding supports former results also in small CEE countries, confirming that involving customers in the innovation process entails a host of new concerns, concepts and managerial decisions (Desouza et al., 2008) and, therefore, firms are changing their innovation strategies from "innovating for customers" to "innovating with customers". Cooperation with suppliers, therefore, appears to be the second significant determinant that can influence innovation in firms, certainly in Estonia and Slovenia. In both countries, innovation processes are not only customerdriven, but knowledge is also leveraged on the supplier side, which makes the innovation processes more balanced and permits 
Tab. 1: Influence of cooperation with different partners on firms' innovation

\begin{tabular}{|c|c|c|c|c|c|}
\hline & Czech R. (CZ) & Slovak R. (SK) & Hungary (HU) & Estonia (ET) & Slovenia (SL) \\
\hline \multicolumn{6}{|c|}{ Private entities } \\
\hline COGP & $.023(.468)^{\star *}$ & $.966(.021)$ & $.083(.441)^{\star}$ & $.000(1.226)^{\star \star *}$ & $.056(.770)^{*}$ \\
\hline COSUP & $.925(.018)$ & $.804(-.128)$ & $.176(.359)$ & $.000(1.026)^{\star \star *}$ & $.000(1.466)^{\star \star *}$ \\
\hline cocus & $.057(.443)^{\star}$ & $.014(1.805)^{\star \star}$ & $.001(.922)^{\star \star \star}$ & $.000(1.614)^{\star \star *}$ & $.000(1.866)^{\star \star \star}$ \\
\hline COCOMP & $.009(1.263)^{\star * *}$ & $.155(-1.094)$ & $.179(.410)$ & $.594(-.237)$ & $.727(-.182)$ \\
\hline \multicolumn{6}{|c|}{ Public entities } \\
\hline COCONS & $.267(.285)$ & $.495(-.441)$ & $.545(.163)$ & $.682(-.189)$ & $.883(.085)$ \\
\hline COUNI & $.028(.485)^{\star *}$ & $.110(1.222)$ & $.000(1.411)^{\star \star \star}$ & $.270(.478)$ & $.020(1.052)^{\star *}$ \\
\hline COGOV & $.103(.734)$ & $.845(.198)$ & $.180(-.501)$ & $.943(.049)$ & $.212(.702)$ \\
\hline
\end{tabular}

Source: own

Note: ${ }^{*}$ statistically significant at $p=.10,{ }^{* *}$ at $p=.05$ and ${ }^{* * *}$ at $p=.01$; Beta coefficients are shown in brackets and denote whether an independent variable (cooperation) caused increase or decrease of firms' innovation activities.

confrontation between customer requirements and suppliers' production opportunities. This is a sign of well-designed strategy even to turn customers to their suppliers (Shankar, 2018) for assistance with innovation.

Cooperation within the group of companies is another vital way to support firms' innovation. Firms that belong to the enterprise group are better informed of the capabilities of potential partners due to knowledge pooling and the activities of other members of their group (Tether, 2002). This kind of cooperation is also essential and significantly influencing innovation outputs in all countries, except Slovakia.

When it comes to public institutions, the concern of cooperation with universities is emerging in particular. During the centrally planned economy, the emphasis was on science and research as such, without their reference to corporate innovations. The official science and technology policy has disrupted the natural relationship of innovation between companies and universities, which is still present in the CEE region. Cooperation with universities, considered as generators of new knowledge, influence partway innovation performance, mainly in the Czech Republic, Hungary and Slovenia. He significant role of universities within the innovation processes was proven by previous studies (e.g. Maietta, 2015; Prokop \& Stejskal, 2017) as knowledge and technology transfer between academia and industry can spur innovation, and this kind of collaboration combines not only heterogeneous partners, but more importantly, heterogeneous knowledge (Rajalo \& Vadi, 2017). On the other hand, cooperation with competitors or other enterprises in the sector, consultants and commercial labs, and with government, public or private research institutes were not significant in most of the cases.

Findings of the logistic regression are encouraging; pointing out that the transition to a market economy with a delay has also encouraged the establishment of relationships between firms and private institutions in favor of boosting innovation performance. In doing so, CEE countries are gradually approaching the behavior of firms in Western European countries. However, there is not a case in innovative cooperation with universities and public institutions; there are apparent differences between countries in collaboration with academia, but low collaboration with public entities can be expected due to so far less efficient public administration in CEE countries. According to the results above, we chose four cooperation partners for further analyses in all countries together.

In the second phase of research on cooperative innovation, all five countries are merged into one dataset with the aim of generalizing the impact of collaboration on innovation performance and explaining them also with regards to the essential characteristics of the companies themselves. The partners in consideration following the previous results are firms within enterprise group, suppliers, 


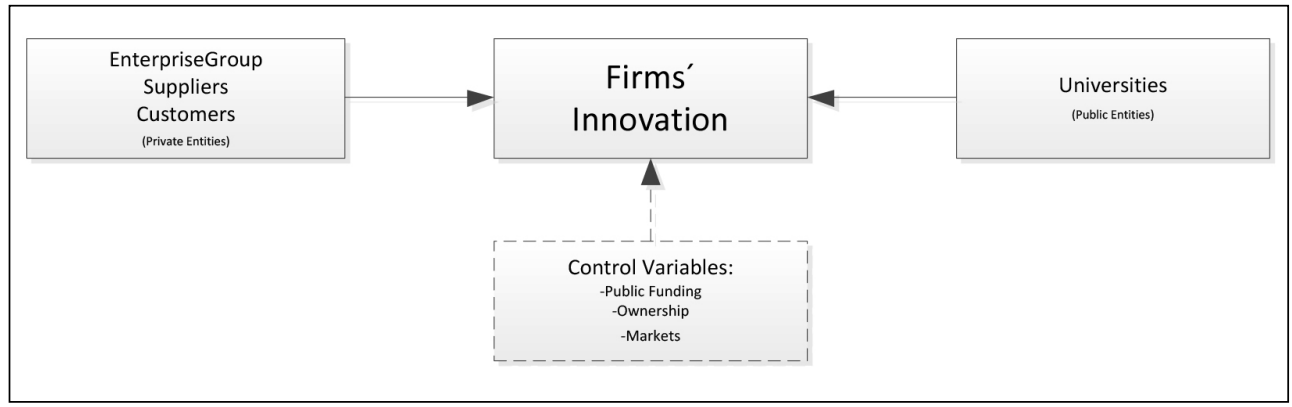

Source: own elaboration

customers, and universities. Moreover, three crucial control variables are added to logistic regression model - market orientation, company's ownership and public financing. This made it possible the build-up following research model (Fig. 2).

Altogether, we subsequently created and tested seven research models to analyze and verify influence and significance of selected cooperation partners on firms' innovation activities. These models differ in including of control variables. In model 1, all control variables are used, in the subsequent models, variables were gradually removed. In that way, models 2-4 were developed using always a combination of two out of three control variables. At the end, models 5-7 were created by using only one out of three control variables.

Results in Tab. 2 show the significance of cooperation within the groups of companies, with suppliers, customers, and universities in the five CEE countries. The relationship between public funding and innovation performance is usually contradictory. Even in this case public

\section{Tab. 2: Influence of cooperation with different partners on firms' innovation}

\begin{tabular}{|c|c|c|c|c|c|c|c|}
\hline & Model 1 & Model 2 & Model 3 & Model 4 & Model 5 & Model 6 & Model 7 \\
\hline & $\begin{array}{l}p \text {-value } \\
B(\exp B)\end{array}$ & $\begin{array}{l}p \text {-value } \\
B(\exp B)\end{array}$ & $\begin{array}{l}p \text {-value } \\
B(\exp B)\end{array}$ & $\begin{array}{l}p \text {-value } \\
B(\exp B)\end{array}$ & $\begin{array}{l}p \text {-value } \\
B(\exp B)\end{array}$ & $\begin{array}{l}p \text {-value } \\
B(\exp B)\end{array}$ & $\begin{array}{l}p \text {-value } \\
B(\exp B)\end{array}$ \\
\hline COGP & \begin{tabular}{|l|}
$.038^{* *}$ \\
$.375(1.455)$ \\
\end{tabular} & $\begin{array}{l}.000^{* * *} \\
1.299(3.667) \\
\end{array}$ & $\begin{array}{l}.032^{* *} \\
.384(1.468) \\
\end{array}$ & $\begin{array}{l}.389 \\
.129(1.137) \\
\end{array}$ & $\begin{array}{l}.000 * * * \\
.811(2.251) \\
\end{array}$ & $\begin{array}{l}.000^{* * *} \\
1.359(3.892) \\
\end{array}$ & $\begin{array}{l}.460 \\
.109(1.115) \\
\end{array}$ \\
\hline COSUP & \begin{tabular}{|l|}
.676 \\
$-.080(.923)$ \\
\end{tabular} & $\begin{array}{l}.000^{\star * *} \\
.752(2.121) \\
\end{array}$ & \begin{tabular}{|l|}
.672 \\
$-.081(.923)$ \\
\end{tabular} & $\begin{array}{l}.779 \\
.041(1.042) \\
\end{array}$ & $\begin{array}{l}.000 * * * \\
.998(2.712)\end{array}$ & $\begin{array}{l}.000^{* * *} \\
.749(2.116) \\
\end{array}$ & \begin{tabular}{|l|}
.794 \\
$.038(1.039)$ \\
\end{tabular} \\
\hline cocus & $\begin{array}{l}.010^{* *} \\
.555(1.741) \\
\end{array}$ & $\begin{array}{l}.002^{* * *} \\
.657(1.930) \\
\end{array}$ & $\begin{array}{l}.011^{\star \star} \\
.553(1.739) \\
\end{array}$ & $\begin{array}{l}.000^{* * *} \\
.813(2.255) \\
\end{array}$ & $\begin{array}{l}.000^{* * *} \\
1.190(3.288)\end{array}$ & $\begin{array}{l}.002^{* * *} \\
.653(1.921) \\
\end{array}$ & $\begin{array}{l}.000^{* * *} \\
.813(2.255) \\
\end{array}$ \\
\hline COUNI & $\begin{array}{l}.026^{\star *} \\
.454(1.574) \\
\end{array}$ & $\begin{array}{l}.000 * \star \star \\
.987(2.682) \\
\end{array}$ & $\begin{array}{l}.025^{\star \star} \\
.457(1.580) \\
\end{array}$ & $\begin{array}{l}.004^{* \star *} \\
.486(1.626)\end{array}$ & $\begin{array}{l}.000^{* * *} \\
1.003(2.728)\end{array}$ & $\begin{array}{l}.000^{\star * *} \\
1.010(2.745)\end{array}$ & $\begin{array}{l}.005^{\star \star *} \\
.480(1.616) \\
\end{array}$ \\
\hline FUND & \begin{tabular}{|l}
.956 \\
$.008(1.008)$ \\
\end{tabular} & & $\begin{array}{l}.964 \\
.007(1.007) \\
\end{array}$ & $\begin{array}{l}.752 \\
-.037(.964) \\
\end{array}$ & & & $\begin{array}{l}.756 \\
-.036(.965) \\
\end{array}$ \\
\hline MAR & $\begin{array}{l}.756 \\
-.045(.956)\end{array}$ & $\begin{array}{l}.011^{\star *} \\
-.288(.750)\end{array}$ & & $\begin{array}{l}.407 \\
.088(1.092)\end{array}$ & $\begin{array}{l}.574 \\
-.045(.956)\end{array}$ & & \\
\hline OWN & $\begin{array}{l}.006^{\star \star *} \\
.405(1.499)\end{array}$ & $\begin{array}{l}.000^{\star * *} \\
.607(1.835)\end{array}$ & $\begin{array}{l}.007^{\star * *} \\
.401(1.494)\end{array}$ & & & $\begin{array}{l}.000^{* * *} \\
.579(1.785)\end{array}$ & \\
\hline
\end{tabular}


funding does not significantly influence firms' innovation activities. The involvement of public support in individual models $(1,3,4,7)$ has led to weakening the effects of different forms of cooperation. Moreover, in Models 4 and 5, the effects of public subsidies were negative and have led to decline of firms' innovation activities. Public funding is aimed at fostering private R\&D activities (Zúñiga-Vicente et al., 2014). However, there is a question to which extent are subsidies efficient. On one hand, public financial support tends to support the creation of technological spillovers in R\&D activities and to prevent market failures and capital market imperfections that hamper firms' ability to access financing (Bronzini \& Piselli, 2016). On the other hand, public funding could lead to allocative inefficiency and crowding-out effects (Cogan et al., 2010). It should be noted that this finding is specific to the CEE countries. It results from a pro-politically defined public subsidy policy, which in itself suffers from a high level of inefficiency due to bureaucracy, low informatization of public administration and a large degree of technical inefficiency. This conclusion is confirmed by the low overall percentage of European CEE funding in recent years.

Second control variable (market orientation) mostly does not influence firms' innovation significantly. At the same time, the influence of market orientation tends to be mostly negative. Therefore, firms oriented on domestic markets are at the side of lower innovation outputs. This is a lesson for the firms to strengthen their foreign orientation, as foreign competitive markets pressure on higher innovativeness. Foreign market orientation includes gaining access to essential inputs, finding low-cost means of production, scale economies, and sales growth (Ojala, 2015).

The last variable in turn means a certain surprise; firm ownership is one of the most significant control variables influencing innovation output. In the countries under study, domestic ownership positively influences intensity firms' innovation. CEE countries in that way show rather different results in comparison to other empirical studies. For example, GërguriRashiti et al. (2017) show significant positive relationship to firms' innovation activities in foreign-owned firms possessing at least $10 \%$ of ownership. This is explained by the large representation of multinational enterprises in small countries that use host countries only to produce and product innovations remain in their headquarters countries. At least, foreign firms enable to host countries access to new technologies having effect of increasing their competitiveness. Furthermore, foreign knowledge and technologies might spill over to domestically owned firms and stimulate their learning and growth as well (Dachs \& Peters, 2014). These results again confirm the assumptions made on the basis of the volume of incoming investment in the economies of CEE countries. FDI is usually a foreign company that has decided to invest in the host economy for various reasons. Public investment incentives also contributed to the decision. If there is a change in the trend, it is also necessary to change the conditions for investment incentives for foreign investors (for example in the direction of higher cooperation with domestic enterprises or their innovation orientation, etc.).

Interesting results could come from research that could divide public-sector and private-sector cooperation. It is clear that there will certainly be spillover effects of innovative potential and innovation performance. This can be perceived as the subject of future research.

\section{Conclusions}

Undoubtedly, innovation is the most studied determinant of economic and social development nowadays. The conclusions of many studies have confirmed that in a globalized economy, businesses have to increase their efforts and look for new opportunities to maintain and strengthen their competitiveness. Businesses go beyond the neoclassical concepts of markets and firms - they collaborate with different stakeholders (both with other businesses and with knowledge-based entities) in innovative processes, which make it possible to access diverse sources of information and various knowledge. Governments at different levels have also increasing interest in business innovation activities. Prosperous businesses enable to achieve regional and other public policy objectives and contribute much more to economic growth (e.g. by higher R\&D investment or infrastructure, hiring more employees). Therefore, it is not unusual for public authorities to support innovative (even other) cooperation between businesses and different actors. The findings of this study show that cooperation has a significant impact 
on the creation of innovation and that public policies have the potential to change (regulate) the behavior of some economic subjects. Therefore, in our opinion, cooperation should become an important determinant, which will be taken into account in defining different government policies.

Likewise, many studies (including ours) have confirmed that innovative processes are also determined by the innovation environment in which economic entities are located. Their influence is not negligible. Therefore the aim of this paper was to analyse co-operation in innovation in small CEE economies and to determine how cooperativeness with different types of private and public partners influences performance in product innovation. The innovation environment and the impact of its components are considerably different. Despite the high rate of economic transition, economic entities in studied small CEE economies have an ever-low ability to co-operate with triple helix partners, low trust, and a low number of facilitators for knowledge or technology transfer. Therefore, it is not possible to apply standard Western innovation performance approaches, but rather to propose their modifications or to seek for the specific models applicable to CEE countries. Our recommendation is to create special partial aids focused on individual precursors or elements leading to barriers and the unwillingness to cooperate both in the private, public and knowledge sectors. Effective instruments can also be used to subsidize programs, and their conditions must be supplemented by cooperation as a conditioning factor.

It has been shown that product innovations are highly dependent on customer collaboration in all analysed countries. This finding supports earlier results in small CEE countries as well, confirming that customer engagement in the innovation process involves a number of new interests, concepts and managerial decisions (Desouza et al., 2008) and therefore firms are changing their innovation strategies from "innovation for customers" to "from customers". This allows businesses to realize better respond to market demand and respond more flexibly to customer needs. An important finding is that collaboration in group of firms is another important way to boost business innovation processes. This type of cooperation is also essential and significantly influences innovation outcomes in all analysed countries except Slovakia. Firms within a group can also use external knowledge flows to improve their absorptive capacity, expand the knowledge base, and benefit from the emerging spillover effects between entities. In addition, participation in a group of firms allows to reduce their own costs, use external resources, or access to new technologies and technology processes, and also to use prestige of entrepreneur group in process of partner for innovation seeking. Interestingly, collaboration with universities shows deficiencies affecting innovation performance insufficiently, especially in the Czech Republic, Hungary and Slovenia. This may also be due to a lack of consistency between the interests of individual subjects (while companies are motivated by higher profits, universities are pursuing entirely different goals - e.g. student numbers, publications, projects). Here again it would benefit from the redefinition of public policies concerning the allocation of research grants or the focus of the institutional research intentions of individual ministerial ministries, or the creation of one government authority managing the grant programs. This would allow a more dynamic conditioning, as well as effective control. The cooperation with competitors or other enterprises in the sector, consultants and commercial laboratories and with government, public or private research institutes has less importance in the analysed economies. Particularly in the context of inefficient cooperation with competitors, it is possible to monitor the lack of trust between competing firms, the lock-in of individual entities and the tendency to protect their own (internal) knowledge and know-how.

When searching for the common determinants of innovation processes in enterprises in the small CEE countries, we found that public financing does not significantly affect innovation activities of companies. Surprisingly the involvement of public funds leads to the weakening of innovation activities. Public funding is generally associated with a great deal of administrative burden, and businesses in many cases will not receive an amount that would be sufficient to generate innovation. These resources are then used in a different way, but they do not lead to the intended effects. Companies in the small CEE countries are often choosing a way to use their internal resources for their own projects or for 
project where they collaborate with universities, or they stop innovation activities. Again, clear recommendations are made - reducing the administrative burden, clearly defining the objectives of grant schemes, reducing the number of approval and decision-making levels, increasing the flexibility of the bureaucratic apparatus due to increased computerization and e-government. Firms' market orientation generally does not significantly affect innovation processes in CEE countries. This makes clear recommendations for companies to adapt their orientation to foreign clients as well. This will broaden potential demand for company production and allow access to other markets. However, foreign orientation also offers better feedback to products, which can boost further innovation activity for businesses and increase their competitiveness. The last remarkable result explains a positive influence of domestic ownership of the firms on the innovation activities. Still, it should be further investigated whether "domestic" does not mean European or otherwise transferred meaning (e.g. ownership by a domestic company founded by foreign companies).

Finally, the limitations of this study must be mentioned. The results are dependent on the quality of the primary data and allow for their interpretation only within the selected spectrum of enterprises in the given CEE countries. A certain weakness of the research is the CIS questionnaire and respondents' response subjectivity (at Eurostat's maximum effort to unify the understanding of questions). Knowing these basic limitations, it is possible to confirm the significance of this research. The selected results then raise further research issues that will be the subject of future research - for example, a comparison of general innovation models applied in Western countries and CEE countries.

This work was supported by a grant provided by the scientific research project of the Czech Sciences Foundation Grant No: 17-11795S.

\section{References}

Beers, C., \& Zand, F. (2014). R\&D cooperation, partner diversity, and innovation performance: an empirical analysis. Journal of Product Innovation Management, 31(2), 292-312. https://dx.doi.org/10.1111/jpim.12096.
Boardman, P. C. (2009). Government centrality to university-industry interactions: University research centers and the industry involvement of academic researchers. Research Policy, 38(10), 1505-1516. https://dx.doi.org/10.1016/j.respol.2009.09.008.

Bock, A. J., Opsahl, T., George, G., \& Gann, D. M. (2012). The effects of culture and structure on strategic flexibility during business model innovation. Journal of Management Studies, 49(2), 279-305. https://dx.doi.org/10.1111/ j.1467-6486.2011.01030.x.

Bogers, M., Zobel, A. K., Afuah, A., Almirall, E., Brunswicker, S., Dahlander, L., ... Hagedoorn, J. (2017). The open innovation research landscape: Established perspectives and emerging themes across different levels of analysis. Industry and Innovation, 24(1), 8-40. https://dx.doi.org/10.1080/ 13662716.2016.1240068.

Brito, L. A. L., Brito, E. P. Z., \& Hashiba, L. H. (2014). What type of cooperation with suppliers and customers leads to superior performance? Journal of Business Research, 67(5), 952-959. https://dx.doi.org/10.1016/j. jbusres.2013.07.015.

Bronzini, R., \& Piselli, P. (2016). The impact of R\&D subsidies on firm innovation. Research Policy, 45(2), 442-457. https://dx.doi. org/10.1016/j.respol.2015.10.008.

Chen, Y., Wang, Y., Nevo, S., BenitezAmado, J., \& Kou, G. (2015). IT capabilities and product innovation performance: The roles of corporate entrepreneurship and competitive intensity. Information \& Management, 52(6), 643-657. https://dx.doi.org/10.1016/j. im.2015.05.003.

Coad, A., \& Rao, R. (2008). Innovation and firm growth in high-tech sectors: A quantile regression approach. Research policy, 37(4), 633-648. https://dx.doi.org//10.1016/j. respol.2008.01.003.

Cogan, J. F., Cwik, T., Taylor, J. B., \& Wieland, V. (2010). New Keynesian versus old Keynesian government spending multipliers. Journal of Economic Dynamics and Control, 34(3), 281-295. https://dx.doi.org/10.1016/j. jedc.2010.01.010.

Collins, C. J., \& Clark, K. D. (2003). Strategic human resource practices, top management team social networks, and firm performance: The role of human resource practices in creating organizational competitive advantage. Academy of Management Journal, 46(6), 740-751. https://dx.doi.org/10.5465/30040665. 
Cooke, P. (2016). The virtues of variety in regional innovation systems and entrepreneurial ecosystems. Journal of Open Innovation: Technology, Market, and Complexity, 2(1), 13. https://dx.doi.org/10.1186/s40852-016-0036-x.

Cvijanović, D., Mihailović, B., Čavlin, M., \& Čavlin, G. (2015). Impact of Marketing Consulting on Performances of Agrarian Clusters in Serbia. Sustainability, 7(2), 10991115. https://dx.doi.org/10.3390/su7021099.

Dachs, B., \& Peters, B. (2014). Innovation, employment growth, and foreign ownership of firms: A European perspective. Research Policy, 43(1), 214-232. https://dx.doi.org/10.1016/j. respol.2013.08.001.

Della Peruta, M. R., Del Giudice, M., Lombardi, R., \& Soto-Acosta, P. (2018). Open innovation, product development, and inter-company relationships within regional knowledge clusters. Journal of the Knowledge Economy, 9(2), 680-693. https://dx.doi. org/10.1007/s13132-016-0356-X.

Desouza, K. C., Awazu, Y., Jha, S., Dombrowski, C., Papagari, S., Baloh, P., \& Kim, J. Y. (2008). Customer-driven innovation. Research-Technology Management, 51(3), 3544. https://dx.doi.org/10.1080/08956308.2008. 11657503.

Figueiredo, P. N., \& Piana, J. (2018). Innovative capability building and learning linkages in knowledge-intensive service SMEs in Brazil's mining industry. Resources Policy, 58, 21-33. https://dx.doi.org/10.1016/j. resourpol.2017.10.012.

Fossas-Olalla, M., Lopez-Sanchez, J. I., \& Minguela-Rata, B. (2010). Cooperation with suppliers as a source of innovation. African Journal of Business Management, 4(16), 34913499.

Friedman, Y., \& Carmeli, A. (2018). The influence of decision comprehensiveness on innovative behaviors in small entrepreneurial firms: the power of connectivity. Innovation, 20(1), 61-83. https://dx.doi.org/10.1080/14479 338.2017.1369141.

Gërguri-Rashiti, S., Ramadani, V., AbaziAlili, H., Dana, L. P., \& Ratten, V. (2017). ICT, innovation and firm performance: the transition economies context. Thunderbird International Business Review, 59(1), 93-102. https://dx.doi. org/10.1002/tie.21772.

Guisado-González, M., González-Blanco, J., Coca-Pérez, J. L., \& Guisado-Tato, M. (2018). Assessing the relationship between
R\&D subsidy, R\&D cooperation and absorptive capacity: An investigation on the manufacturing Spanish case. The Journal of Technology Transfer, 43(6), 1647-1666. https://dx.doi. org/10.1007/s10961-017-9579-7.

Hashi, I., \& Stojčić, N. (2013). The impact of innovation activities on firm performance using a multi-stage model: Evidence from the Community Innovation Survey 4. Research Policy, 42(2), 353-366. https://dx.doi. org/10.1016/j.respol.2012.09.011.

Hudec, O. (2015). Visegrad countries and regions: Innovation performance and efficiency. Quality Innovation Prosperity, 19(2), 55-72. https://dx.doi.org/10.12776/qip.v19i2.593.

Hudec, O., \& Prochádzková, M. (2018). The Evolution of Innovation Networks in Slovakia: Disintegration and Slow Recovery. In J. Stejskal, P. Hajek, \& O. Hudec (Eds.), Knowledge Spillovers in Regional Innovation Systems (pp. 133-161). Cham: Springer, https://dx.doi.org/10.1007/978-3-319-67029-4_5.

Hudec, O., et al. (2007). Štatistické metódy $v$ ekonomických vedách. Košice: Technická univerzita v Košiciach.

Ketata, I., Sofka, W., \& Grimpe, C. (2015). The role of internal capabilities and firms' environment for sustainable innovation: evidence for Germany. R\&D Management, 45(1), 60-75. https://dx.doi.org/10.1111/radm.12052.

Klomp, L., \& Van Leeuwen, G. (2001). Linking innovation and firm performance: a new approach. International Journal of the Economics of Business, 8(3), 343-364. https:// dx.doi.org/10.1080/13571510110079612.

Lööf, H., \& Heshmati, A. (2006). On the relationship between innovation and performance: A sensitivity analysis. Economics of Innovation and New Technology, 15(4-5), 317-344. https://dx.doi. org/10.1080/10438590500512810.

Lööf, H., Heshmati, A., Asplund, R., \& Nåås, S. O. (2001). Innovation and performance in manufacturing industries: A comparison of the Nordic countries [SSE/EFI working paper series in economics and finance. No. 457].

Maietta, O. W. (2015). Determinants of university-firm R\&D collaboration and its impact on innovation: A perspective from a low-tech industry. Research Policy, 44(7), 1341-1359. https://dx.doi.org/10.1016/j.respol.2015.03.006.

Mateut, S. (2018). Subsidies, financial constraints and firm innovative activities in emerging economies. Small Business 
Economics, 50(1), 131-162. https://dx.doi. org/10.1007/s11187-017-9877-3.

Minguela-Rata, B., Fernández-Menéndez, J., \& Fossas-Olalla, M. (2014). Cooperation with suppliers, firm size and product innovation. Industrial Management \& Data Systems, 114(3), 438-455. https://doi.org/10.1108/IMDS-08-2013-0357.

Nieves, J., Quintana, A., \& Osorio, J. (2016). Organizational knowledge and collaborative human resource practices as determinants of innovation. Knowledge management research \& practice, $14(3), 237-245$. https://dx.doi. org/10.1057/kmrp.2014.26.

Ojala, A. (2015). Geographic, cultural, and psychic distance to foreign markets in the context of small and new ventures. International Business Review, 24(5), 825-835. https://dx.doi.org/10.1016/j.ibusrev.2015.02.007.

Ozkaya, H. E., Droge, C., Hult, G. T. M., Calantone, R., \& Ozkaya, E. (2015). Market orientation, knowledge competence, and innovation. International Journal of Research in Marketing, 32(3), 309-318. https://dx.doi. org/10.1016/j.jiresmar.2014.10.004.

Prokop, V., \& Stejskal, J. (2017). Different approaches to managing innovation activities: An analysis of strong, moderate, and modest innovators. Engineering Economics, 28(1), 47-55. https://dx.doi.org/10.5755/j01.ee.28.1.16111.

Rajalo,S.,\&Vadi,M.(2017).University-industry innovation collaboration: Reconceptualization. Technovation, 62,42-54. https://dx.doi.org/10.1016/j. technovation.2017.04.003.

Ramadani, V., Abazi-Alili, H., Dana, L. P., Rexhepi, G., \& Ibraimi, S. (2017). The impact of knowledge spillovers and innovation on firm-performance: findings from the Balkans countries. International Entrepreneurship and Management Journal, 13(1), 299-325. https://dx.doi.org/10.1007/s11365-016-0393-8.

Retherford, R. D., \& Choe, M. K. (2011). Statistical Models for Causal Analysis. New York: John Wiley.

Ritala, P., Husted, K., Olander, H., \& Michailova, S. (2018). External knowledge sharing and radical innovation: the downsides of uncontrolled openness. Journal of Knowledge Management, 22(5), 1104-1123. https://dx.doi. org/10.1108/JKM-05-2017-0172.

Ritala, P., Olander, H., Michailova, S., \& Husted, K. (2015). Knowledge sharing, knowledge leaking and relative innovation performance: An empirical study. Technovation, 35, 22-31. https://dx.doi.org/10.1016/j.technovation.2014.07.011.
Romer, P. M. (1990). Endogenous technological change. Journal of Political Economy, 98(5), Part 2, S71-S102. https://dx.doi.org/10.1086/261725.

Sánchez-González, G., González-Álvarez, N., \& Nieto, M. (2009). Sticky information and heterogeneous needs as determining factors of R\&D cooperation with customers. Research Policy, 38(10), 1590-1603. https://dx.doi. org/10.1016/j.respol.2009.09.012.

Schneider, S., \& Spieth, P. (2013). Business model innovation: Towards an integrated future research agenda. International Journal of Innovation Management, 17(1). https://dx.doi. org/10.1142/S136391961340001X.

Shankar, B. (2018). Customer Innovation Bias. In Nuanced Account Management (pp. 171-183). Singapore: Palgrave Macmillan.

Tavassoli, S. (2018). The role of product innovation on export behavior of firms: Is it innovation input or innovation output that matters? European Journal of Innovation Management, 21(2), 294-314. https://dx.doi. org/10.1108/EJIM-12-2016-0124.

Tavassoli, S., \& Karlsson, C. (2016). Innovation strategies and firm performance: Simple or complex strategies? Economics of Innovation and New Technology, 25(7), 631-650. https://dx.doi.org/ 10.1080/10438599.2015.1108109.

Tether, B. S. (2002). Who co-operates for innovation, and why: an empirical analysis. Research Policy, 31(6), 947-967. https://dx.doi. org/10.1016/S0048-7333(01)00172-X.

Trippl, M., \& Bergman, E. M. (2014). Clusters, Local Districts, and Innovative Milieux. In Handbook of Regional Science (pp. 439-456). Springer Berlin Heidelberg.

Varblane, U., Dyker, D., Tamm, D., \& von Tunzelmann, N. (2007). Can the national innovation systems of the new EU member states be improved? Post-Communist Economies, 19(4), 399-416. https://dx.doi. org/10.1080/14631370701680048.

Wang, C., Rodan, S., Fruin, M., \& Xu, X. (2014). Knowledge networks, collaboration networks, and exploratory innovation. Academy of Management Journal, 57(2), 484-514. https://dx.doi.org/10.5465/amj.2011.0917.

Wright, P. M., Gardner, T. M., Moynihan, L. M., \& Allen, M. R. (2005). The relationship between HR practices and firm performance: Examining causal order. Personnel Psychology, 58(2), 409-446. https://dx.doi.org/10.1111/ j.1744-6570.2005.00487.x. 
Wu, J. (2014). Cooperation with competitors and product innovation: Moderating effects of technological capability and alliances with universities. Industrial Marketing Management, 43(2), 199-209. https://dx.doi.org/10.1016/j. indmarman.2013.11.002.

Xiang, D., Chen, J., Tripe, D., \& Zhang, N. (2018). Family firms, sustainable innovation and financing cost: Evidence from Chinese hi-tech small and medium-sized enterprises. Technological Forecasting and Social Change. https://dx.doi.org/10.1016/j. techfore.2018.02.021.

Zúñiga-Vicente, J. Á., Alonso-Borrego, C., Forcadell, F. J., \& Galán, J. I. (2014). Assessing the effect of public subsidies on firm R\&D investment: a survey. Journal of Economic Surveys, 28(1), 36-67. https://dx.doi. org/10.1111/j.1467-6419.2012.00738.x.
Ing. Viktor Prokop, Ph.D. University of Pardubice Faculty of Economics and Administration Czech Republic Jan.Stejskal@upce.cz

Assoc. Prof. Ing. Jan Stejskal, Ph.D. University of Pardubice Faculty of Economics and Administration Czech Republic viktor.prokop@upce.cz

Prof. RNDr. Oto Hudec, PhD. Technical University of Kosice Faculty of Economics Slovakia oto.hudec@tuke.sk 


\section{Abstract}

\section{COLLABORATION FOR INNOVATION IN SMALL CEE COUNTRIES}

\section{Viktor Prokop, Jan Stejskal, Oto Hudec}

The innovative environment and its elements are crucial determinants of the innovation activity of enterprises in developed economies. Also public authorities also focus on innovation environment development, which are being implemented with financial support from public budgets. In developed countries, these incentives are geared to promoting cooperation, as it is a key element of any innovative environment. In Western economies, a certain Western innovation model is being implemented. However, its application in the CEE countries is significantly limited due to the specific characteristics of these economies. Therefore, the main focus of the paper is to examine the impact of cooperation with different types of innovation partners on product innovation performance of manufacturing companies in small CEE countries.

In the first phase of the research, CIS data (from Eurostat) and its own regression models identify the types of co-operating partners (private and public) that have the most significant impact on product innovation (researched separately in selected CEE countries). In the second part, the model is constructed so as to identify the predictors, the variables having a significant impact on product innovations across countries (using a merged dataset from all analysed CEE countries). To expand knowledge about innovation and business performance, three variables were added to the model as control variables: market orientation, company ownership, and public funding. The combined dataset of the five CEE countries was again used to examine the impact of different types of co-operating partners on product innovation through a binary logistic regression model.

Findings of logistic regression are encouraging; pointing out that the transition to a market economy with a delay has also encouraged the establishment of relationships between firms and private institutions in favour of boosting innovation performance. In doing so, CEE countries are gradually approaching the behaviour of firms in Western European countries.

Key Words: Innovation, innovation activity and absorption, CEE countries, determinant.

JEL Classification: O38, O47, H50, C33.

DOI: 10.15240/tul/001/2019-1-009 